\title{
Antibiotic Resistance Profile of Escherichia coli Isolated from Bovine Subclinical Mastitis of Dairy Farms in Algeria from 2017 to 2019
}

\author{
Loubna Ghallache ${ }^{1}$, Abdellah Mohamed-Cherif ${ }^{2}$, Bernard China ${ }^{3}$, Faiza Mebkhout ${ }^{4,5}$, Nesrine Boilattabi ${ }^{6}$, Alaoua \\ Bouchemal $^{7}$, Ahmed Rebia ${ }^{5}$, Ammar Ayachi ${ }^{1}$, Djemel Khelef ${ }^{2}$, Kamel Miroud $^{8}$, and Khatima Ait-Oudhia ${ }^{2,9 *}$ \\ ${ }^{I}$ Environment, Health, and Animal Production Laboratory, Institute of Veterinary and Agronomic Sciences, Batna, Algeria \\ ${ }^{2}$ High National Veterinary School, Algiers, rue Issad Abbes, El Alia, Oued Smar, Algiers. Algeria \\ ${ }^{3}$ Sciensano, The Belgian Institute of Health, 1050 Brussels, Belgium \\ ${ }^{4}$ Institute of Veterinary Sciences. University Saad Dahleb Blida 1, Algeria \\ ${ }^{5}$ ITELV, Les zouines. BP 03/A, 16000. Birtouta, Algérie \\ ${ }^{6}$ Laboratory of Cellular and Molecular Biology. FSB. USTHB, Algiers, Algeria \\ ${ }^{7}$ CNIAAG. BP $N^{\circ} 10$ Birtouta Algiers, Algeria \\ ${ }^{8}$ Laboratoire Epidémio-surveillance, santé, productions et reproduction, expérimentation et thérapie cellulaire des animaux domestiques et sauvages \\ (ESSPRETCADS) ». Institut des Sciences Vétérinaires. Université Chadli Bendjedid El-Tarf, Algeria \\ ${ }^{9}$ Laboratory of Biotechnology in Animal Reproduction, Blida, Algeria \\ *Corresponding author's Email: khatima.aitoudhia@gmail.com; (D) ORCiD: 0000-0002-2514-5615
}

\begin{abstract}
Mastitis in cows is a major problem in dairy farms leading to a decrease in the quantity and quality of milk. The aim of the present study was to examine the association between the presence of Escherichia coli $(E$. coli) in milk and the subclinical mastitis, and to characterize the antibiotic resistance profiles of the isolated $E$. coli. In the current study, a total of 360 cow raw milk samples from three dairy farms of the region of Algiers were analyzed. The analysis period lasted from Spring 2017 to Winter 2019. The California Mastitis Test (CMT) was applied to detect subclinical mastitis. The E. coli strains were isolated from milk using conventional bacteriological methods. The antibiotic resistance profile of the isolated $E$. coli strains to 12 different antibiotics was tested using the disk diffusion method. On $\beta$-lactamase-producing strains, a double diffusion test was applied to identify the Extendedspectrum $\beta$-lactamase (ESBL) phenotype. Finally, the $c t X x-M$ genes were amplified by PCR. Two-thirds $(66.4 \%)$ of the milk samples were positive for the CMT test. A total of $97 \mathrm{E}$. coli strains were isolated from the milk samples, their resistance to antibiotics was tested, and $3.1 \%$ of the strains were resistant to trimethoprim-sulfamethoxazole, $6.2 \%$ to chloramphenicol, $12.3 \%$ to gentamicin, $13.4 \%$ to colistin, $23.3 \%$ to amoxicillin/clavulanate, $31.9 \%$ to kanamycin, $39.2 \%$ to enrofloxacin, $51.5 \%$ to cefotaxime, $52 \%$ to tetracycline, $57.7 \%$ to ampicillin, $74.3 \%$ to nalidixic acid, and $75.3 \%$ to amoxicillin. Furthermore, most of the E. coli strains (92.8\%) were resistant to more than one antibiotic with a Multiple Antibiotic Resistance index ranging from 0 to 0.8 . The 50 strains resistant to cefotaxime were analyzed for an ESBL phenotype. 39 of them (78\%) were positive to the double-disk synergy test. Among the 39 ESBL positive strains, 27 (69.2\%) were confirmed for the presence of a CTX-M gene by PCR. The present study showed that multiple drug-resistant E. coli, including ESBL-carriers, were frequently isolated from the milk of dairy cows in Algeria. The results underlined that the use of antibiotics on farms must be reasoned to avoid the spread of resistant strains in animals and human populations.
\end{abstract}

Keywords: Antibiotic Resistance, Cows, CTX-M gene, Escherichia coli, Milk, Subclinical Mastitis

\section{INTRODUCTION}

Algerian people are great milk consumers (120 1/inhabitant/year) but the local production is insufficient to fulfill this demand. The imported milk is expensive (around 1 trillion USD per year) for Algeria (MADR, 2003), therefore, Algerian authorities encourage local milk production. It is, thus, necessary to increase the local milk production yield. According to the Ministry of Agriculture and Rural Development (MADR), Algeria has a herd of 900000 dairy cows, including 23000 high potential dairy cattle (MADR, 2003). To achieve the goal of increasing the quantity and quality of milk production in Algeria, it is important to study the physiology of milk production and identify the causes that may affect it.

However, mastitis is the most expensive and the most important disease in the dairy industry. It is defined as an inflammation of one or more quarters of the mammary gland, characterized by physical, chemical, and microbiological changes in milk secretion as well as pathological changes in breast tissue (Sharif and Muhammad, 2009). The economic losses are due to the low yield of infected udders, veterinary treatments, milk seizures as well as the premature culling of cows (Peton and Le Loir, 2014). 
Clinical mastitis infections are those with symptoms like udder swelling or redness that are clearly visible. On the other hand, subclinical mastitis infections do not cause any visible changes in milk or udder appearance, making it difficult to detect. Nevertheless, subclinical mastitis infections affect the dairy producer's bottom line by reducing milk production, decreasing milk quality, and suppressing reproductive performance.

Regarding the incidence of subclinical mastitis, an average annual cost of around 5000 euros has been estimated in a herd of 100 dairy cows in the Netherlands (Halasa et al., 2009). However, the presence of pathogens and/or toxins in milk as well as residues of antibiotics resulting from the treatment of mastitis can seriously compromise public health. These infections are mainly caused by coliform bacteria Escherichia coli (E. coli), staphylococci, and streptococci (Baazise, 2006). The E. coli is the signature of fecal contamination although Staphylococci and Streptococci are members of the skin microbiota. To fight mastitis, massive doses of antibiotics are used selecting resistant and multiresistant bacteria in milk.

The present study was dedicated to the characterization of antibiotic-resistant E. coli in the milk of dairy cows in dairy farms of the Algiers region from Spring 2017 to Winter 2019.

\section{MATERIALS AND METHODS}

\section{Ethical approval}

Since the experiments were performed on naturally collected milk, no ethical question was raised by this study. The samples were taken under the supervision of a veterinarian.

\section{Sampling}

A total of 360 milk samples $(50 \mathrm{~mL})$ coming from 149 different cows in three different farms (Figure 1) located in the region of Algiers were analyzed. The dairy farms in Algeria were rather small (less than 100 head of cattle) and the production system is mostly semi-intensive (MADR, 2003). Except for farm 2, the cows had access to meadows. The characteristics of the sampled farms are listed in Table 1. In order to examine a possible evolution in time, certain cows were sampled several times at different time periods. Therefore, the number of milk samples was higher than the number of cows.
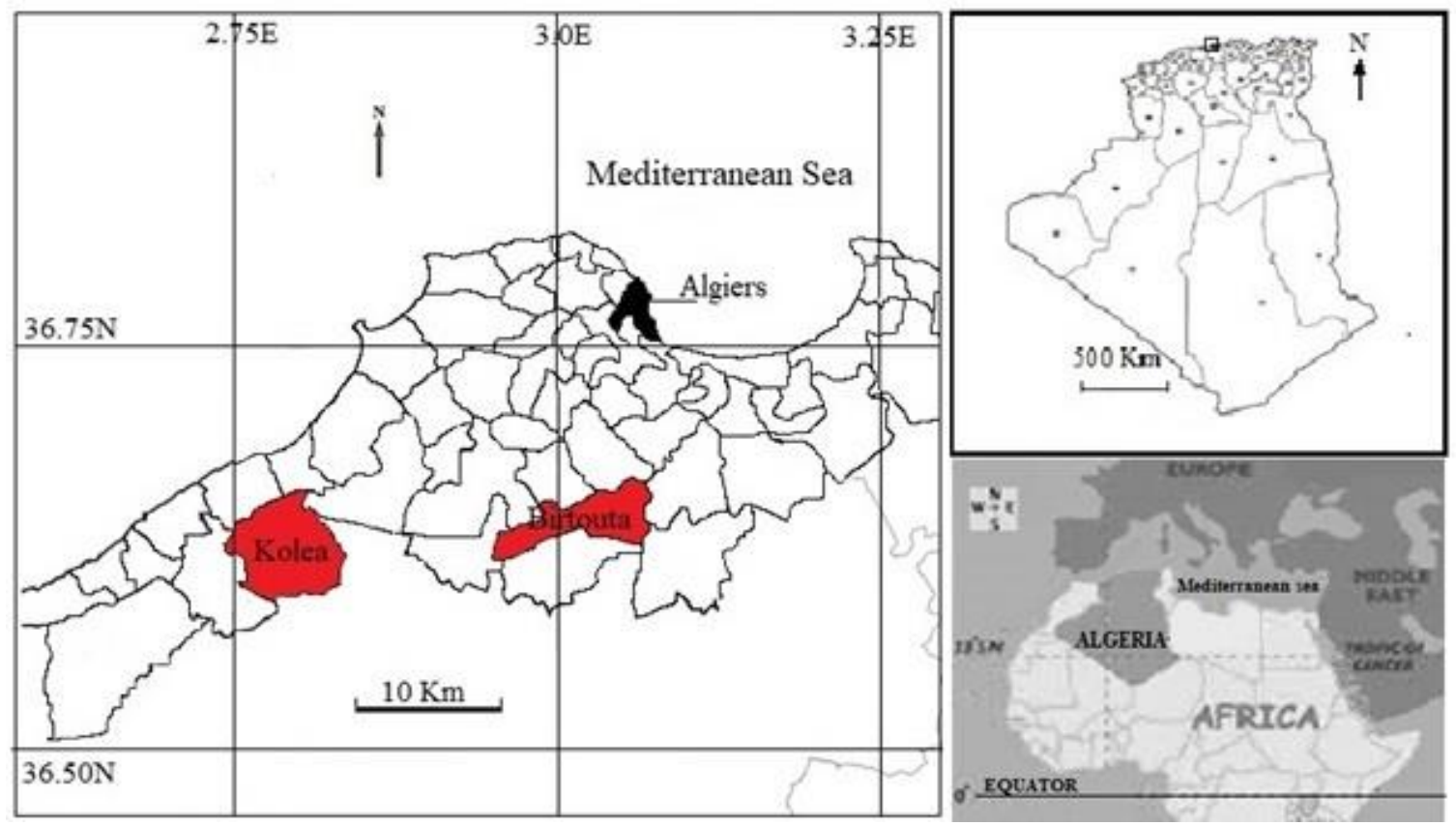

Figure 1. Localization of the sampled farms of the Algiers region

Table 1. Characteristics of the farms of the Algiers region

\begin{tabular}{|c|c|c|c|c|c|}
\hline Farm & Name & $\begin{array}{c}\text { Location (town and GPS } \\
\text { coordinates) }\end{array}$ & $\begin{array}{c}\text { Number of } \\
\text { sampled cows }\end{array}$ & $\begin{array}{l}\text { Number of } \\
\text { milk samples }\end{array}$ & Period of sampling \\
\hline Farm 1 & DOUMA & Kolea, $\left.36^{\circ} 36^{\prime} 05.3^{\prime \prime} \mathrm{N} 2^{\circ} 47^{\prime} 00.5^{\prime \prime E}\right)$ & 32 & $120 *$ & March to May 2017 \\
\hline Farm 2 & CNIAAG & Birtouta $36^{\circ} 39^{\prime} 21.8^{\prime \prime} \mathrm{N} 3^{\circ} 01 ' 27.3^{\prime \prime} \mathrm{E}$ & 76 & 180 & April to July 2019 \\
\hline Farm 3 & ITELV & Birtouta $36^{\circ} 39^{\prime} 13.9^{\prime \prime} 3^{\circ} 03^{\prime} 05.4^{\prime \prime} \mathrm{E}$ & 41 & 60 & April to December 2019 \\
\hline Total & & & 149 & 360 & $\begin{array}{c}\text { March } 2017 \text { to December } \\
2019\end{array}$ \\
\hline
\end{tabular}

*: In this farm a sample of the bulk milk tank was also analyzed. 


\section{California mastitis test}

The California Mastitis Test (CMT) was employed on farms to identify subclinical mastitis by an indirect estimation of the Somatic Cell Count (SCC) in milk (Leach et al., 2008). A four-well plastic paddle was used, one well per udder quarter of the cow to be tested. Foremilk was discarded, and then about 50-100 ml of the milk was collected into each well. An equal volume of test reagent was added (COVETO, Montaigu, France), and gently manually agitated. The reaction was scored on a scale of 0 (mixture remained unchanged) to 3 (almost-solid gel forms), with a score of 2 or 3 being considered as a positive result. A cow was considered positive if at least one quarter was positive.

\section{Microbiological analysis}

In this phase of the study, $1 \mathrm{ml}$ of each milk sample was used to inoculate a sterile tube containing $9 \mathrm{ml}$ of Brain Heart Infusion Broth (BHIB, Oxoid, Basingstoke, UK). The tubes were incubated for 24 hours at $37^{\circ} \mathrm{C}$. For the isolation of $E$. coli, a droplet of the enrichment medium was used to inoculate a Tryptone Bile X-glucuronide (TBX) Agar (Oxoid CM0945, Basingstoke, UK) plate using a sterile loop. The plates were incubated 24 hours at $37^{\circ} \mathrm{C}$. The characteristic colonies were picked and streaked on a selective medium Basing (Hektoen Agar, Oxoid PO0142, Basingstoke, UK) to obtain a pure culture. For bacterial identification, catalase, oxidase, and coagulase tests were performed (Pilet and Bourdon, 1979).

The antibiotic resistance of the isolated E. coli strains was analyzed using the disk diffusion method (Brown and Kothari, 1975). The diameters of inhibition were measured and compared according to the instructions by The European Committee on Antimicrobial Susceptibility Testing (EUCAST) guidelines (SFM, 2019) to determine the phenotype (sensitive, intermediate, or resistant). The used antibiotics are listed in Table 2. The antibiotics were chosen following the recommendations of the Algerian Ministry of Health (MSPRH, 2014).

Multiple Antibiotic Resistance (MAR) index was defined as diving the number of resistant antibiotics by the number of tested antibiotics (Krumperman, 1983). For ESBL producers, the double-disk synergy test was used as previously described (Drieux et al., 2008). Commercially available disks (Oxoid, Basingstoke, UK) of Cefotaxime $(\mathrm{CTX}, 30 \mu \mathrm{g})$ together with $30 \mu \mathrm{g}$ Amoxicillin-clavulanate (AMC) were placed $25 \mathrm{~mm}$ apart from each other on the surface of inoculated Muller-Hinton Agar (MHA) plate and incubated at $37^{\circ} \mathrm{C}$ for 24 hours. The test was considered positive when the decreased susceptibility to CTX and/or ceftazidime was associated with a clear augmentation of inhibition zone in front of the AMC antibiotic disk forming a characteristic "champagne cork" shape (Okoko et al., 2020). As a confirmation test, CTX $(30 \mu \mathrm{g})$ disk and AMC $(30 \mu \mathrm{g})$ were placed $30 \mathrm{~mm}$ apart on the surface of inoculated MHA, and incubated for one hour. Then, the AMC disk was removed and replaced by a CTX disk (30 $\mu \mathrm{g})$, and the plate was incubated at $37^{\circ} \mathrm{C}$ for 24 hours following the recommendations of the Algerian Ministry of Health (MSPRH, 2014).

\section{Molecular detection of resistance genes}

The E. coli strains that were positive for the double-disk synergy test (ESBL+) were analyzed for the presence of blaCTX-M genes using PCR as previously reported by Tabar et al. (2016). The forward and reverse primers used for PCR were bla-CTX-M-F 5'-ACCGCCGATAATTCGCAGAT-3' and bla-CTX-M-R 5'GATATCGTTGGTGGTGCCATA -3, respectively (Tabar et al., 2016). Briefly, $1 \mathrm{ml}$ of an overnight $E$. coli culture in BHI (Bio-Rad, France) was used to prepare DNA by the boiling method (Djahnit et al., 2018). To amplify the CTX-M gene by PCR, $5 \mu \mathrm{l}$ of the DNA was used. The master mix consisted of $4 \mu \mathrm{l}$ of $5 \mathrm{X}$ PCR Mix (miniPCR, USA), $0.2 \mu 1$ of each primer $(40 \mu \mathrm{M}$, Eurogentec, Belgium), and $10.6 \mu \mathrm{l}$ of DNAse-RNAse free sterile water (miniPCR, USA). The PCR temperature cycles were applied once $\left(94^{\circ} \mathrm{C}\right.$ for 5 minutes), followed by 40 times $\left(94^{\circ} \mathrm{C}\right.$ for 30 seconds, $58.0^{\circ} \mathrm{C}$ for 30 seconds, and $72^{\circ} \mathrm{C}$ for 30 seconds), and finally once $\left(72^{\circ} \mathrm{C}\right.$ for 5 minutes). The PCR products were analyzed by $2 \%$ gel agarose electrophoresis (Green and Sambrook, 2019). A 584 bp product was expected. Two controls were used, namely a CTX-M15+ E. coli strain (DSM22664, DSMZ, Germany) and a CTX-M-2+ E. coli strain (provided by the Belgian National reference center of antibiotic-resistant Gram-negative bacilli, Yvoir, Belgium).

\section{Statistical analysis}

The statistical analyses were performed using the following free online statistics software. MedCalc (version 20.009, Schoonjans, 2017) was used for the odds ratios. For the independence Chi-Square test, BiostatGV (version 2020) was used (Huet et al., 2021). The confidence interval for the proportions was calculated using Sample size.net (version 2021, Kohn and Senya, 2021). For the hierarchical clustering, Wessa (version 1.2.1.) was used (Wessa, 2021) with the option complete linkage. All the statistics used in this work were described in the textbook by Thrusfield and Christley (2018).

The association strength between the presence of $E$. coli in milk samples and the CMT test results was performed using the Odds Ratio (OR) calculation (Thrusfield and Christley, 2018). A case sample was defined as a sample contaminated by E. coli and a control sample as an E. coli free sample. The association among antibiotic resistance profiles was calculated using the independence Chi-square test (Thrusfield and Christley, 2018). In order to accept or 
reject the null hypothesis, the following rules were adopted; $\mathrm{p}$ value $<0.01$ was considered as a highly significant difference, $\mathrm{p}$ value $<0.05$ was considered as a significant difference, and a $\mathrm{p}$ value $\geq 0.05$ was considered as nonsignificant.

Hierarchical clustering analysis of the E. coli strains was made using the complete linkage method (Guess and Wilson, 2002). Briefly, a table was made with one row for each strain and one column for each antibiotic. The result of the antibiotic resistance was scored as zero for sensitive, one for resistant, and two for intermediate. The table was then used to introduce the data (as a Comma-separated Value (CSV) file) in a statistic software in R language (Wessa, 2021). The dendrogram was generated, and the length of the bars (height) indicated the distance among the strains.

Table 2. The list of used antibiotics with the disk loads and the used cut-offs

\begin{tabular}{lcc}
\hline Antibiotic & Diskload $(\boldsymbol{\mu g})$ & Cut-off (mm) \\
\hline Ampicillin (AMP) & 10 & $13-17$ \\
\hline Amoxicillin (AMX) & 20 & $13-17$ \\
\hline Amoxicillin/Clavulanate (AMC) & $30(20-10)$ & $13-18$ \\
\hline Nalidixic acid (NAL) & 30 & $13-19$ \\
Cefotaxim (CTX) & 30 & $22-26$ \\
Gentamicin (GEN) & $25(1.25-23.75)$ & $12-15$ \\
\hline Trimethoprim- Sulfamethoxazole (SXT) & 30 & $10-16$ \\
\hline Chloramphenicol (CHL) & 25 & $12-18$ \\
\hline Colistin (CST) & 30 & $10-11$ \\
\hline Tetracycline (TET) & 10 & $14-19$ \\
\hline Kanamycin (KAN) & 5 & $13-18$ \\
\hline Enrofloxacin (ENR) & 5 & $16-21$ \\
\hline
\end{tabular}

\section{RESULTS}

\section{California mastitis test}

In farm 1 (Douma), 120 milk sampling were collected from 32 cows. Of 120 milk samples, 78 (65\%, CI 95\%: 55.873.5) were positive to the CMT test, moreover, 31 cows (96.9\%) showed at least one positive sample. In order to evaluate an evolution in time, one cow was sampled six times, 25 cows were sampled four times, two cows were samples three times, three cows were sampled two times, one cow was sampled once, and the bulk tank milk was also analyzed. Considering the obtained results, 14 out of 32 cows (43.75\%, CI 95\%: 26.36-62.34) presented 100\% of the positive samples, 3 cows presented $75 \%$ of the positive samples, 1 cow presented $66.67 \%$ of the positive samples, 4 cows presented $50 \%$ of positive samples, 1 cow presented $33.3 \%$ of positive samples, 7 cows presented $25 \%$ of positive samples, and only 2 cows presented no positive sample. Concerning the evolution of the positivity of the samples in time, no clear pattern appeared. In farm 2 (CNIAAG), 180 milk samples coming from 78 cows were analyzed, 90 samples (50\%, CI 95\%: 42.5-57.5) were positive to the CMT test. Moreover, 57 out of 78 cows (73.1\%, CI 95\%: 61.882.5) showed at least one positive sample. Three cows were sampled four times, 37 cows were sampled three times, 19 cows were sampled two times and 19 cows were sampled once. Twenty-five out of 78 cows $(32.1 \%)$ presented $100 \%$ of the positive samples, one $(1.3 \%)$ cow presented $75 \%$ of the positive samples, one $(1.3 \%)$ cow presented $66.67 \%$ of the positive samples, 7 (9\%) cows presented $50 \%$ of positive samples, $17(21.8 \%)$ presented $33.3 \%$ of positive samples, and $31(39.7 \%)$ presented no positive samples. In farm 3 (ITELV), 60 milk sampling were performed on 40 cows; 51 samples (85\%, CI 95\%: 73.4-92.9) were positive. Thirty-three of the cows (82.5\%, CI 95\%: 67.2-92.7) showed at least one positive sample. Two cows were sampled three times, 16 cows were sampled twice, and 22 cows were sampled once. Furthermore, 31 out of 41 cows $(77.5 \%)$ showed $100 \%$ of positive samples, 2 presented $50 \%$ of positive samples and 7 cows generated no positive results.

Globally, 239 out of 360 (66.39\%, CI 95\% 61.25-71.25) samples were positive to the CMT test, and121 cows out of 150 (80.67\%. CI 95\%: 73.43-86.65) showed at least one positive sample. These results indicated a severe problem of subclinical mastitis in these farms.

\section{Escherichia coli isolation}

The results of the research on E. coli in the 360 milk samples (Table 3) indicated an overall prevalence of $26.9 \%$ (97/360). Therefore, the next step was to investigate if there was a correlation between CMT results and E. coli isolation 
results (Table 4). The Odds ratio was significantly upper than one indicating an association between the presence of $E$. coli in the milk sample and the presence of a positive CMT test $(\mathrm{p}<0.05)$.

\section{Antibiotic sensitivity testing}

The main purpose of this study was to examine the antibiotic resistance of isolated $E$. coli. The obtained results of the first serial of 12 antibiotics are summarized in Figure 2. Of the 97 tested E. coli strains, 1 was resistant to 10 different antibiotics, containing Ampicillin (AMP), Amoxicillin (AMX), Amoxicillin/Clavulanate (AMC), Cefotaxim (CTX), Trimethoprim-sulphamethoxazole (SXT), Chloramphenicol (CHL), Colistin sulfate (CST), Tetracycline (TET), Kanamycin (KAN), Nalidixic acid (NAL), five strains (5.2\%) were resistant to eight different antibiotics (AM, AMX, AMC, CTX, CHL, K, NAL, Enrofloxacin (ENR)), nine strains (9.3\%) were resistant to seven antibiotics, 22 strains $(22.7 \%)$ were resistant to six antibiotics, $19(19.6 \%)$ were resistant to five antibiotics, $11(11.3 \%)$ were resistant to four antibiotics, eight strains $(8.2 \%)$ were resistant to three antibiotics, $12(12.4 \%)$ were resistant to two antibiotics, four $(4.1 \%)$ were resistant to one antibiotic and only three strains $(3.2 \%)$ were sensitive to all the tested antibiotics. Among them, two strains were isolated from two different cows of farm 2 (CNIAAG) and one stain from farm 1 (DOUMA). In other words, the MAR index was in the range of 0-0.8.

Interestingly, out of 97 strains, 85 (97.6\%) different resistant types (resist types) were observed. Some clusters per farm were found as expected, but since it does not always indicate that similar resist types can be observed in different farms (Figure 3). The antibiotic resistances of the E. coli isolated were compared per antibiotic and among the farms in Table 5. There was a significant difference among AMP, AMC, CTX, CHL, TET, KAN, and ENR ( $\mathrm{p}<0.01)$.

The association among the resistances was also investigated (Figure 4). The results indicated that the AMP resistance profile was statistically associated with the AMC resistance, the CTX resistance, the TET resistance, the KAN resistance, and the ENR resistance $(\mathrm{p}<0.05)$. The AMX resistance was associated with the KAN resistance, the NAL resistance, and the ENR resistance $(\mathrm{p}<0.01)$. The AMC resistance was associated with CTX and CST resistance ( $<$ 0.05). The CTX resistance was associated with the CST and the KAN resistance ( $<0.05)$. The GEN resistance was associated with the SXT resistance $(\mathrm{p}<0.01)$. The SXT resistance was associated with the CHL $(\mathrm{p}<0.01)$. The KAN resistance was associated with the NAL and with the ENR resistance $(\mathrm{p}<0.05)$. The NAL resistance was associated with the ENR resistance $(\mathrm{p}<0.01)$.

\section{Extended-spectrum beta-lactamases}

Among the $E$. coli tested samples, some seemed to potentially have an Extended Spectrum $\square$-lactamase phenotype (ESBL). The double-disk synergy test has been performed on the 50 E. coli strains resistant to CTX, among which 39 strains presented a characteristic phenotype (Figure 5). The gene CTX-M encoding CTX-M $\square$-lactamase was amplified by PCR on the 39 potentially ESBL + E. coli. 27 out of the $39(69.2 \%)$ tested E. coli strains were CTX-M positive (Figure 6).

Table 3. Escherichia coli isolated strains from milk samples found in the different farms of the Algiers region

\begin{tabular}{lcc}
\hline Farm* & Number of milk samples & Number of E.coli contaminated milk $(\%)$ \\
\hline Farm 1(DOUMA) & 120 & $45(37.5 \%)$ \\
Farm 2 (CNIAAG) & 180 & $30(16.7 \%)$ \\
Farm 3 (ITELV) & 60 & $22(36.7 \%)$ \\
Total & 360 & $97(26.9 \%)$ \\
\hline
\end{tabular}

*: The farms are described in material and methods

Table 4. Association between the presence of Escherichia coli in milk samples and the results of California Mastitis test for cows of the studied farms of the Algiers region

\begin{tabular}{lcc}
\hline & Case $(\boldsymbol{E}$. coli +$)$ & Control $(\boldsymbol{E}$. coli -$)$ \\
\hline Exposed (CMT +) & 74 & 147 \\
Not exposed (CMT-) & 23 & 116 \\
Exposure rate (\%) & 76.3 & 55.9 \\
Odds & 3.2 & 1.3 \\
\hline Odds ratio (CI 95\%) & & $2.5(1.5-4.3)$ \\
P-value & $<0.05$ & \\
\hline
\end{tabular}

CMT: California Mastitis Test, CI: Confidence Interval, E. Coli: Escherichia coli 
Table 5. Comparison of the antibiotic resistance of Escherichia coli per antibiotic in the different farms of the Algiers region

\begin{tabular}{|c|c|c|c|c|c|}
\hline Antibiotic* & Farm & $\mathbf{S}$ & I & $\mathbf{R}$ & $\begin{array}{c}\text { p-value (Khi2 } \\
\text { test) }\end{array}$ \\
\hline \multirow{3}{*}{ AMP } & CNIAAG & 3 & 1 & 27 & \multirow{3}{*}{$\begin{array}{l}<0.01 \\
\text { SS }\end{array}$} \\
\hline & DOUMA & 31 & 4 & 10 & \\
\hline & ITELV & 0 & 1 & 20 & \\
\hline \multirow{3}{*}{ AMX } & CNIAAG & 4 & 2 & 25 & \multirow{3}{*}{$\begin{array}{l}0.1 \\
\text { NS }\end{array}$} \\
\hline & DOUMA & 12 & 3 & 30 & \\
\hline & ITELV & 1 & 0 & 20 & \\
\hline \multirow{3}{*}{ AMC } & CNIAAG & 9 & 10 & 12 & \multirow{3}{*}{$\begin{array}{l}<0.01 \\
\mathrm{SS}\end{array}$} \\
\hline & DOUMA & 32 & 2 & 11 & \\
\hline & ITELV & 7 & 14 & 0 & \\
\hline \multirow{3}{*}{ CTX } & CNIAAG & 11 & 0 & 20 & \multirow{3}{*}{$\begin{array}{l}<0.01 \\
\text { SS }\end{array}$} \\
\hline & DOUMA & 24 & 0 & 21 & \\
\hline & ITELV & 1 & 11 & 9 & \\
\hline \multirow{3}{*}{ GEN } & CNIAAG & 28 & 1 & 2 & \multirow{3}{*}{$\begin{array}{l}0.2 \\
\text { NS }\end{array}$} \\
\hline & DOUMA & 37 & 0 & 8 & \\
\hline & ITELV & 19 & 0 & 2 & \\
\hline \multirow{3}{*}{ SXT } & CNIAAG & 23 & 8 & 0 & \multirow{3}{*}{$\begin{array}{c}0.07 \\
\text { NS }\end{array}$} \\
\hline & DOUMA & 27 & 15 & 3 & \\
\hline & ITELV & 19 & 2 & 0 & \\
\hline \multirow{3}{*}{ CHL } & CNIAAG & 21 & 9 & 1 & \multirow{3}{*}{$\begin{array}{c}<0.01 \\
\mathrm{SS}\end{array}$} \\
\hline & DOUMA & 41 & 0 & 4 & \\
\hline & ITELV & 20 & 0 & 1 & \\
\hline \multirow{3}{*}{ CST } & CNIAAG & 23 & 0 & 8 & \multirow{3}{*}{$\begin{array}{c}0.04 \\
\text { SI }\end{array}$} \\
\hline & DOUMA & 38 & 3 & 4 & \\
\hline & ITELV & 20 & 0 & 1 & \\
\hline \multirow{3}{*}{ TET } & CNIAAG & 17 & 3 & 11 & \multirow{3}{*}{$\begin{array}{c}<0.01 \\
\mathrm{SS}\end{array}$} \\
\hline & DOUMA & 12 & 11 & 22 & \\
\hline & ITELV & 2 & 0 & 19 & \\
\hline \multirow{3}{*}{ KAN } & CNIAAG & 17 & 1 & 13 & \multirow{3}{*}{$\begin{array}{c}<0.01 \\
\mathrm{SS}\end{array}$} \\
\hline & DOUMA & 40 & 1 & 4 & \\
\hline & ITELV & 4 & 2 & 15 & \\
\hline \multirow{3}{*}{ NAL } & CNIAAG & 4 & 2 & 25 & \multirow{3}{*}{$\begin{array}{l}0.2 \\
\text { NS }\end{array}$} \\
\hline & DOUMA & 12 & 3 & 30 & \\
\hline & ITELV & 2 & 0 & 19 & \\
\hline \multirow{3}{*}{ ENR } & CNIAAG & 4 & 14 & 13 & \multirow{3}{*}{$\begin{array}{c}<0.01 \\
\mathrm{SS}\end{array}$} \\
\hline & DOUMA & 24 & 9 & 12 & \\
\hline & ITELV & 1 & 6 & 14 & \\
\hline
\end{tabular}

S: sensitive; R: resistant; I: intermediate; SI: significant; SS: very significant; NS: not significant. * AMP: Ampicillin, AMX: Amoxicillin, AMC: Amoxicillin/Clavulanate, NAL: Nalidixic acid, CTX: Cefotaxim, GEN: Gentamicin, SXT: Trimethoprim-Sulfamethoxazole, CHL: Chloramphenicol, CST: Colistin, TET: Tetracycline, KAN: Kanamycin, ENR: Enrofloxacin

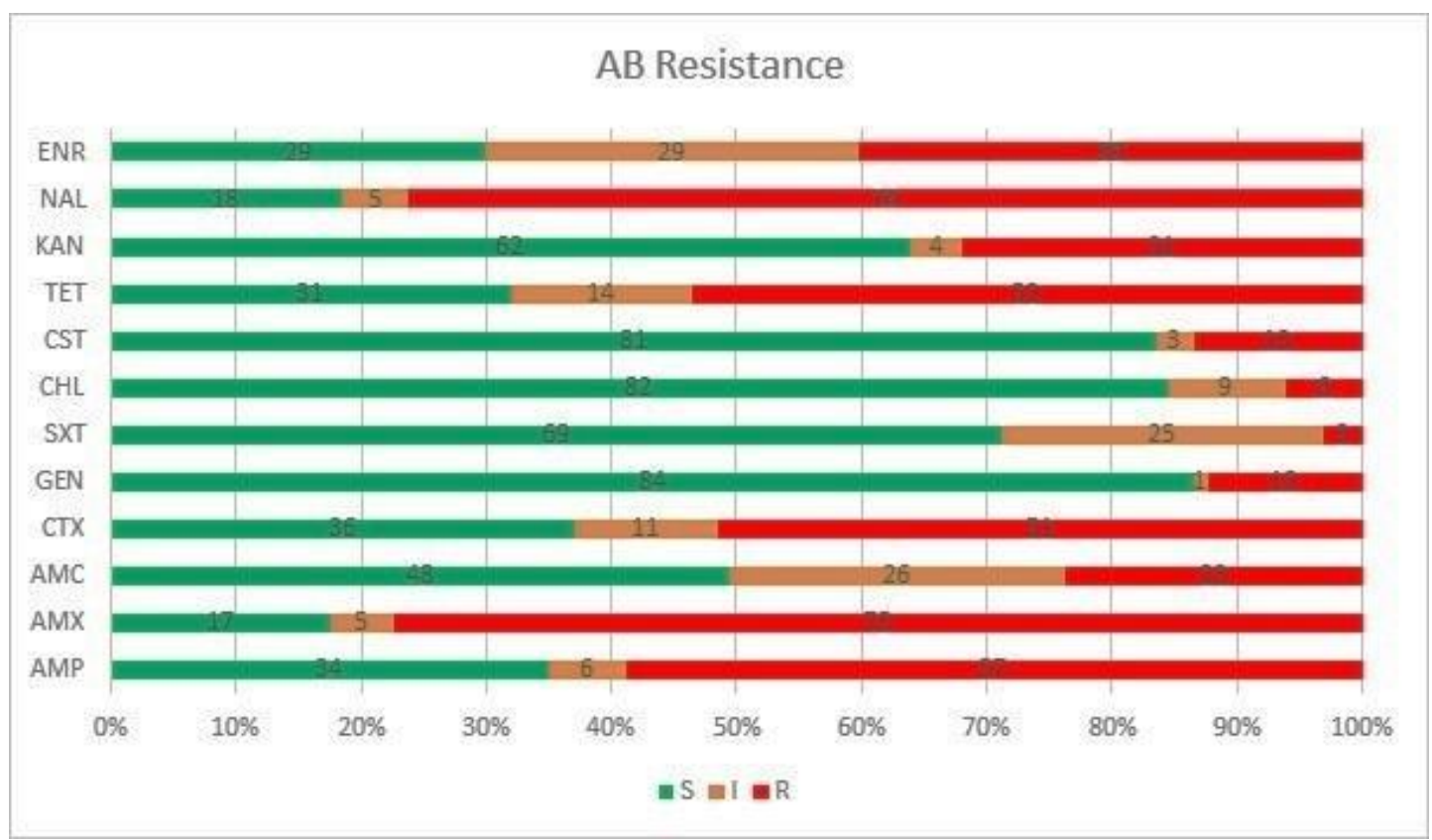

Figure 2. Resistance profile for 12 different antibiotics of the 97 Escherichia coli isolates from the farms of the Algiers region. AMP: Ampicillin, AMX: Amoxicillin, AMC: Amoxicillin/Clavulanate, NAL: Nalidixic acid, CTX: Cefotaxim, GEN: Gentamicin, SXT: Trimethoprim-Sulfamethoxazole, CHL: Chloramphenicol, CST: Colistin, TET: Tetracycline, KAN: Kanamycin, ENR: Enrofloxacin, S: Sensitive, R: Resistant, I: Intermediate. 


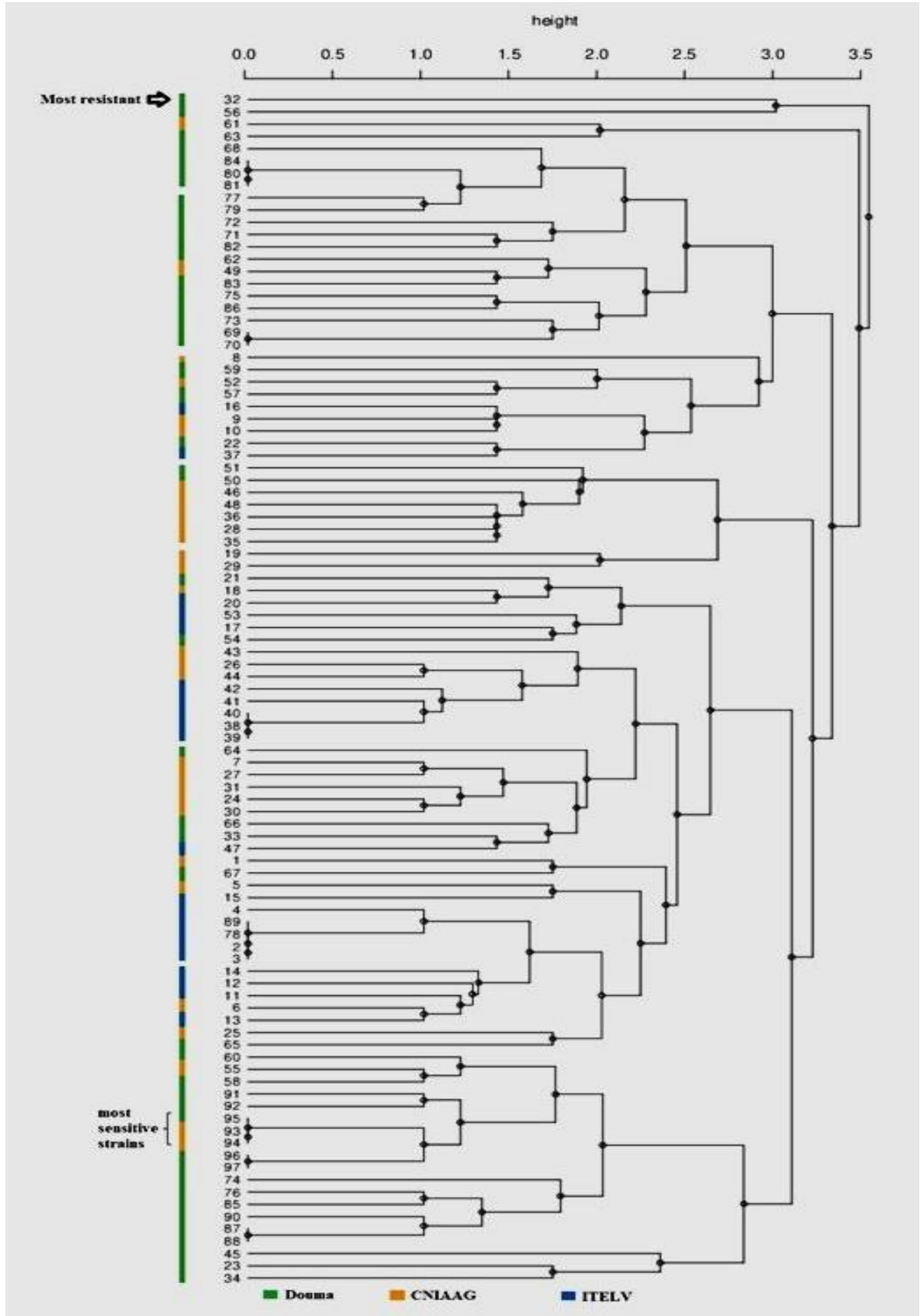

Figure 3. Dendrogram comparing the antibiotic resistance profiles of the 97 Escherichia coli strains. The Escherichia coli isolates were numbered from 1 to 97. The colors indicated the farm where the Escherichia coli strain was isolated. The length of the lines is proportional to the distance among the strains (Defays, 1977) 


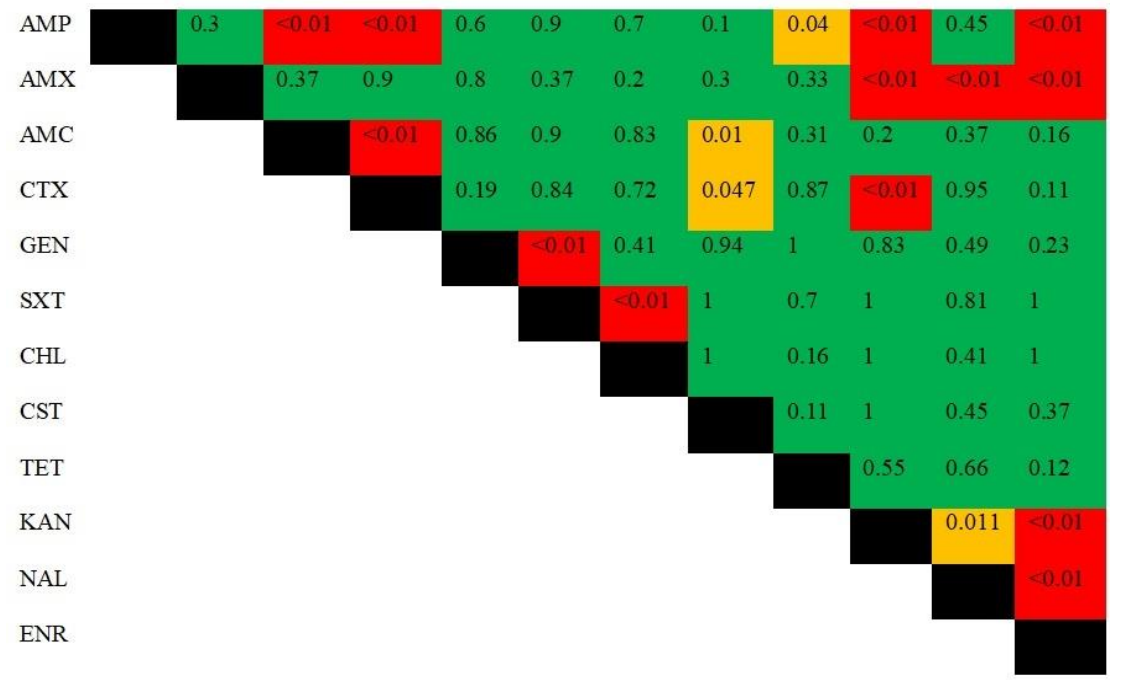

Figure 4. Associations among resistances. An independence chi 2 test has been applied. The p values of the Chi 2 test were indicated. In green $(p \geq 0.05)$; there was no association, in orange $(0.05<p<0.01)$, there was a significant association; and in red ( $p<0.01)$, there was a significant association. AMP: Ampicillin, AMX: Amoxicillin, AMC: Amoxicillin/Clavulanate, NAL: Nalidixic acid, CTX: Cefotaxim, GEN: Gentamicin, SXT: Trimethoprim-Sulfamethoxazole, CHL: Chloramphenicol, CST: Colistin, TET: Tetracycline, KAN: Kanamycin, ENR: Enrofloxacin.
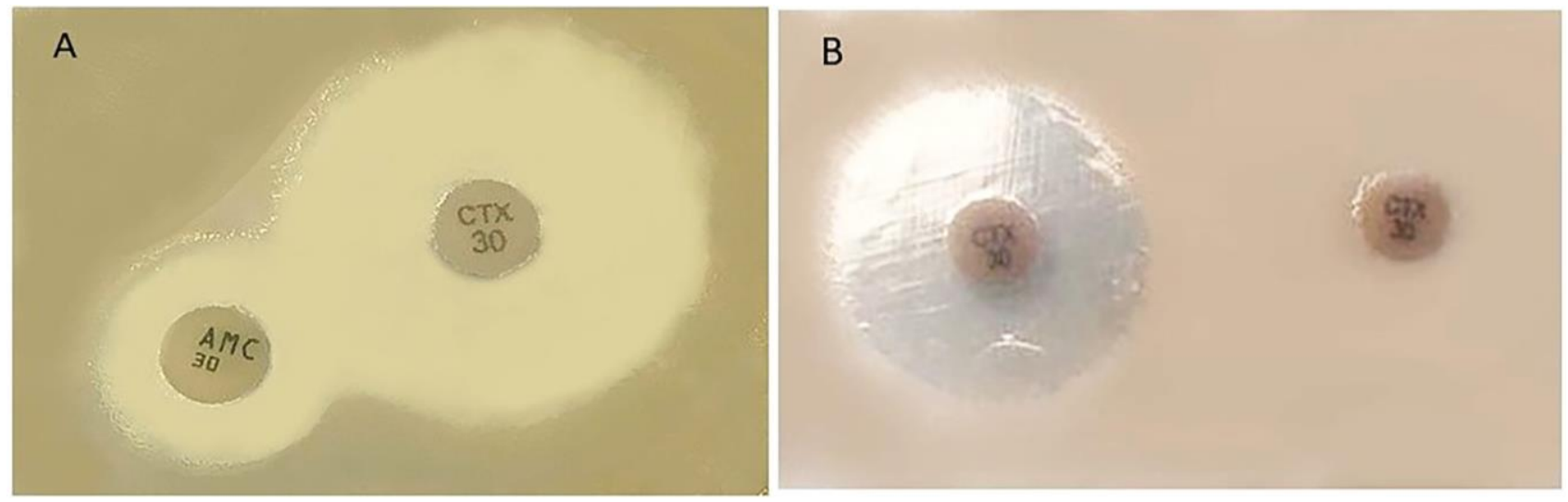

Figure 5. ESBL phenotype identification using synergy and double disk profiles. A: Synergy profile between AMC (30 $\mu \mathrm{g})$ and CTX $(30 \mu \mathrm{g})$. Due to clavulanate inhibition of ESBL; B: Double disk profile. The CTX $(30 \mu \mathrm{g})$ disk on the left showed a classical inhibition phenotype. The CTX $(30 \mu \mathrm{g})$ disk on the right showed no inhibition due to the pre-incubation for one hour with an AMC $(30 \mu \mathrm{g})$ disk.

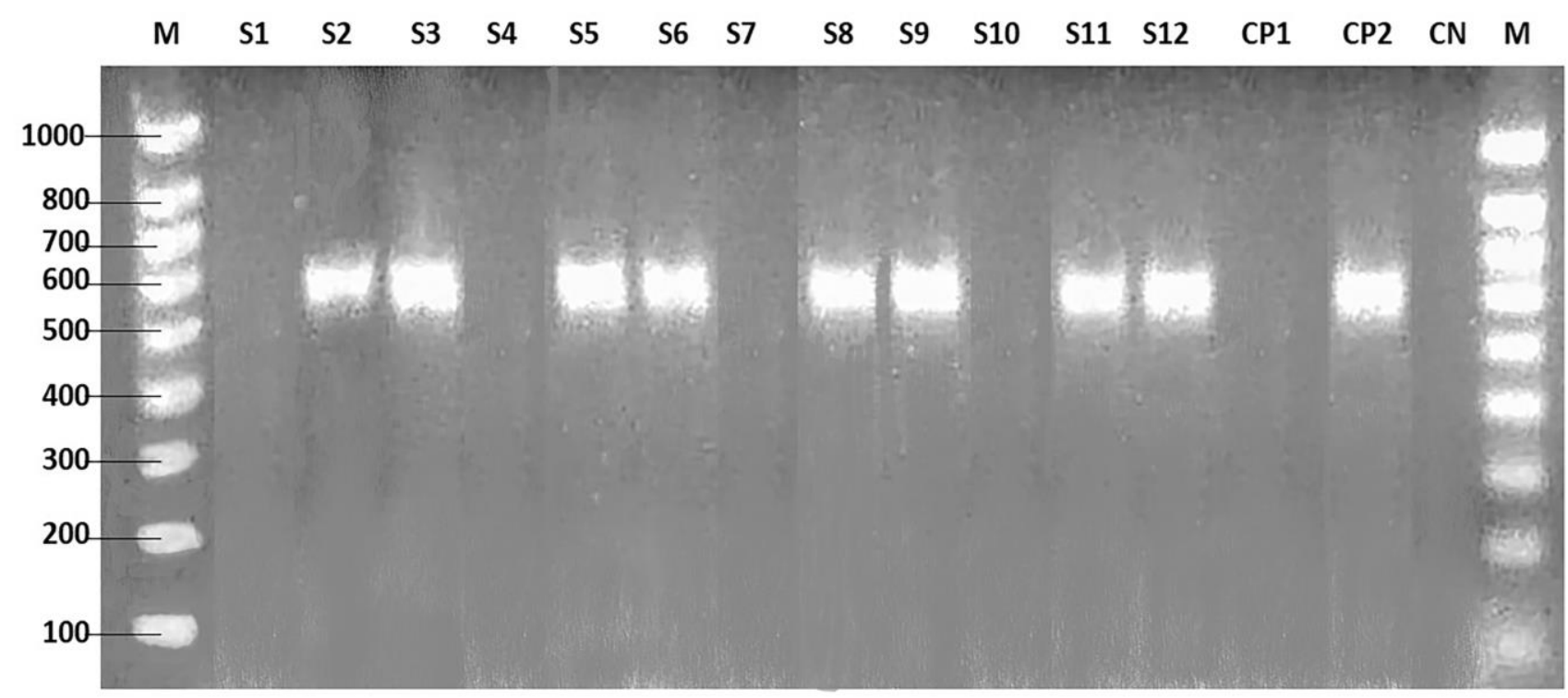

Figure 6. Agarose gel electrophoresis (2\%). M: molecular weight ladder (bp). S1, S4, S7, S10: negative samples. S2, S3, S5, S6, S8, S9, S11, S12: positive samples. CP1: CTX-M-1 + strain; CP2: CTX-M-2 strain; CN: Negative PCR control. 
Mastitis is a common inflammation of the cow udder leading to defect in milk production quantitatively and qualitatively leading to economic losses. In the present study, $239(66.4 \%)$ cows presented a positive CMT test which was in accordance with the previous study in Algeria where $79 \%$ of the tested cows were CMT + (Asnoune et al., 2012), and with the study on milk quality in West Algeria (Aggad et al., 2009). Escherichia coli can harbor and transmit resistance to antibiotics. The virulence and the antibiotic resistance of bacteria are often linked (Cepas and Soto, 2020). Escherichia coli is one of the bacteria causing mastitis along with Staphylococci and Streptococci (Burvenich et al., 2003). Given its origin, it is not normal to find this bacterium in milk indicating fecal contamination.

In the current study, the prevalence of $E$. coli in milk samples was $26.94 \%$. When this prevalence was compared with the prevalence of other studies of the literature, the present prevalence is high. For instance, a prevalence of $6.5 \%$ was found in Jordan (Ismail and Abutarbush, 2020), 10\% in Mexico (Olivares-Pérez et al., 2015), 11.1\% in China (Yu et al., 2020), 15.5\% in Belgium (Verbeke et al., 2014) and 7\% in Egypt (Ameen et al., 2019). Interestingly, the present $E$. coli prevalence in the current study was approximately close to the prevalence $(26 \%)$ found in another recent study in Algeria (Tahar et al., 2020) or a study in Ethiopia (27.3\%) (Haftu et al., 2012), and lower than the prevalence found in Tunisia (31.7\%) (Saidani et al., 2018).

A positive association (OR > 1) was observed between the presence of E. coli and a CMT+ test. Indeed, E. coli is a bacterium often found in mastitis (Burvenich et al., 2003). The hygiene of the farm is very often involved in the contamination of milk by E. coli. Heavily soiled litter is a major source of contamination (Magnusson et al., 2007). Decontamination of udders during milking is especially important to eliminate bacterial contaminations as much as possible. Therefore, the presence of $E$. coli in milk is an indicator of the lack of hygiene during milking (Saidani et al., 2018). The generalization of antibiotic therapy has produced spectacular results in the treatment of mastitis. But it has an unfortunate corollary, the selection of Multi-Drug Resistant (MDR) germs. In addition, previous studies have shown that the use of antibiotics for many years has acted as a selection agent of an antibiotic-resistant bacterial population on the farm prior to antibiotic use for a new clinical purpose (Avrain et al., 2003; Boonyasiri et al., 2014).

Food-producing animals harbor bacteria in their intestinal tract include potentially pathogenic bacteria for humans. These bacteria could serve as reservoirs of resistance determinants that could spread throughout the food chain, reducing the effectiveness of antimicrobials used in human and veterinary medicine (Gouvêa et al., 2015; Manyi-Loh et al., 2018).

The obtained results of the current study revealed a wide variation in resistance to the tested antibiotics. The resistance phenotype ranged from $3.1 \%$ (SXT) to $75.3 \%$ (AMX). It is worth mentioning that most of the E. coli strains (90/97, 92.8\%) were MDR with a MAR index ranging from 0 to 0.8 with one strain resisting to 10 out of the 12 tested antibiotics. The presence of MDR strains was due to the significant pressure exerted by the extensive use of antibiotics on the farms analyzed. The appearance of MDR strains was favored by different mechanisms, including a resistance mechanism leading to the resistance of more than one antibiotic (efflux pump), the horizontal transfer of resistance by mobile genetic elements such as plasmids or transposons, and the presence of strains with a high mutation rate (Chang et al., 2015).

Recently in Algeria, multidrug-resistant E. coli in cows with clinical mastitis in 42 different dairy farms have been investigated (Tahar et al., 2020). The antimicrobial susceptibility testing was performed by the disk diffusion method on 52 E. coli strains. The observed resistances were AMX (86.5\%), TET (75\%), AMC (59.6\%), SXT (36.5\%), doxycycline $(13.5 \%)$, and ciprofloxacin (13.5\%). Multidrug resistance was observed in 38.4\% of isolates (Tahar et al., 2020). In a similar study in Egypt (Ameen et al., 2019), the E. coli strains isolated from cow milk were resistant to AM (33\%), SXT (23\%), and TET (16\%) or AMC (6.6\%). In Switzerland (Nüesch-Inderbinen et al., 2019), the E. coli strains isolated from cow milk were resistant to AM (22\%), TET (16\%), SXT $(9.8 \%)$, gentamicin $(3.7 \%)$, or to AMC (2.4\%). The observed differences in the different studies were mostly dependent on the used antibiotics in the farms. Therefore, SXT was the best choice in the present study, although AMC was the most appropriate choice in the Egyptian and Swiss studies.

The study of resistor types of the different strains underlined the existence of clusters in the same farm. Nevertheless, some similar resistance profiles were present in different farms. It is related to the fact that the same antibiotics were used in different farms (Österberg et al., 2016). When the resistance per antibiotic was compared among the farms, significant differences $(p<0.05)$ were observed for the prevalence of the resistance to several antibiotics (AMP, AMC, TET, KAN, and ENR). Therefore, the circulating strains were not the same for the different farms. It is due to the used antibiotics in the farms, and to the fact that the sampling period was not the same for all the farms. When the resistance is considered by the antibiotic family, the results were observed as follows; quinolones, NAL, and ENR (a fluoroquinolone) were tested. In fact, $74.3 \%$ and $39.2 \%$ of the E. coli strains were resistant to nalidixic acid and ENR, respectively. The resistances were significantly associated $(\mathrm{p}<0.01)$, which is logical since the mechanisms of resistance were similar (mutations chromosomal genes gyrA and parE). The high levels of resistance can be related to the large use of ENR by the veterinarians in the sampled farms (personal communication).

For fluoroquinolones, a recent study in Algeria indicated $13.5 \%$ of the resistance of E. coli strains isolated from cow milk against ciprofloxacin (Tahar et al., 2020). In that study, the sampled region was located $200 \mathrm{~km}$ southeast of the current sampling region. The differences can be related to the fact that different antibiotics were used by veterinarians in this region. For example, in this study (Tabar et al; 2020), the most prevalent resistance was resistance to AMX (86.5\%), TET (75\%), and AMC (59.6\%). In Tunisia, in a similar study, $11 \%$ of the E. coli isolates were resistant to ENR (Saidani et al., 2018).

For sulfonamides, the resistance against SXT in the present study was low (3\%) compared to the data of the literature for comparative studies. For example, the resistance rate was 23.3\% in Egypt (Ameen et al., 2019) or 17.8\% in Tunisia (Burvenich et al., 2003). But the results indicated 25\% of intermediate resistance which is concerning. 
Nevertheless, a low rate of resistance was also found in Canada (5.8\%) (Saini et al., 2012). For TET, the resistance rate was $52 \%$. In the same country for a similar survey, the resistance rate was $75 \%$ (Tahar et al., 2020). The same high level of resistance rate was observed in Tunisia (46.6\%) (Saidani et al., 2018) or Brazil (92\%) (Rangel and Marin, 2009). Tetracycline represents one of the oldest molecules used, both in therapy and preventively, generating remarkably high resistance.

Nevertheless, in regions where this antibiotic was used less, lower resistance rates were recorded, for instance, the rates were reported as 2.6\% in Canada (Saini et al., 2012), 12\% in China (Yu et al., 2020), as well as 16.66\% (Ameen et al., 2019) and 27.5\% in Egypt (Ombarak et al., 2018). Tetracycline has been used inappropriately in animal feed in many countries, leading to the development of resistance. This has prompted some countries to prohibit their use in animal feed, such as in European countries (OJEU, 2003).

For aminoglycosides, KAN and gentamicin were tested. Following the classification (Saberfar et al., 2008), the results indicated that the resistance rate of the strains found in the current study for KAN goes to group II of middle resistance with a resistance level of $31.9 \%$. The resistance to KAN was significantly different $(\mathrm{p}<0.01)$ among the tested farms with a farm presenting $71.4 \%$ of resistant E. coli. Kanamycin resistance was significantly associated (p < 0.02) with the resistance to beta-lactam antibiotics (AMP, AMX, and CTX), and to resistance to quinolones (NAL and ENR). These associations need to be investigated because these antibiotics belong to different families and the resistance mechanisms are different. Moreover, such association was not found for gentamycin.

The high sensitivity of $E$. coli strains to gentamicin was due to the non-use of this antibiotic in veterinary treatments in Algeria, and therefore, no selection of resistant strains. The prevalence of KAN-resistant E. coli isolated from cow milk was within the range of 2.8\% in China (Yu et al., 2020), $4.1 \%$ in Egypt (Ombarak et al., 2018), and 6\% in France (Botrel et al., 2010).

For gentamicin, a rate of $12 \%$ was recorded which was close to what has been recorded in Tunisia (19.5\%, Saidani et al, 2018), in Egypt (13.3\%, Ameen et al, 2019), and In China (12\%, Yu et al, 2020). In addition, the present results were extremely low compared to those reported in Brazil (Rangel and Marin, 2009), Lebanon (Barbour et al., 2015), or Iran (Fazel et al., 2019), where the reported rates were 67.9\%, 77\%, and 49.2\%, respectively. For polymixins, colistin (polymyxin E) has been tested. Colistin is a cationic polypeptide antibiotic that interacts with the outer membrane of gram-negative bacteria. Despite colistin once was avoided due to its nephro-and neurotoxicity, this drug has now become a last-resort antimicrobial agent for treating life-threatening infections caused by MDR gram-negative bacteria. However, in November 2015, the first plasmid-borne colistin resistance gene $m c r-1$, encoding a phosphoethanolamine transferase, was detected in livestock and raw meat samples as well as humans in China (Liu et al., 2020).

In the current study, $13.4 \%$ of the E. coli strains were resistant to colistin. Colistin resistance was associated (p < 0.05) with CTX resistance. Interestingly, colistin and ESBL resistance are plasmid-borne, and can be co-transferred as previously described in China (Liu et al., 2020). It will be, therefore, interesting to study the plasmid profiles of the isolated strains to identify the genetic support of the colistin resistance.

$\beta$-lactamins are classical antibiotics interfering with cell wall synthesis. In the present study, several $\beta$-lactamins were tested; AMP, AMX, AMC, and CTX. 75.3\% of the E. coli strains were resistant to AMX, 57.7\% to AM, 51.5\% to CTX, and $23.3 \%$ to AMC. Therefore, $\beta$-lactamin resistance is common in the analyzed farms. The resistance of $E$. coli strains to AMP ranged widely, 2.6\% in Canada (Saini et al., 2012), 22\% in Switzerland (Nüesch-Inderbinen et al., 2019), $31.7 \%$ in China (Yu et al., 2020), 33.3\% in Egypt (Ameen et al., 2019), and 59\% in Brazil (Rangel and Marin, 2009).

The resistance to AMX was $86.6 \%$ in a similar study in another region of Algeria (Tahar et al., 2020), confirming that the E. coli strains resistant to AMX are common in cow milk suffering from mastitis in Algeria. Nevertheless, the use of a combination of AMC dropped the resistance rate to $23.7 \%$ in the current study and to $59.6 \%$ in the other Algerian study (Tahar et al., 2020), which was was confirmed in other studies conducted in Brazil (Rangel and Marin, 2009) and Egypt (Ameen et al., 2019) decreasing from 58\% to $14 \%$ and $33.3 \%$ to $6.7 \%$, respectively.

For CTX, the resistance rate was $4.5 \%$ in Egypt (Ombarak et al., 2018) and 18.1\% in China (Yu et al., 2020). Therefore, the observed resistance rate in the current study was quite high indicating that E. coli strains producing $\beta$ lactamases were common in Algeria. This increase is particularly worrying because third-generation cephalosporins have been classified as critically important antibiotics (Collignon et al., 2009). Among the different mechanisms involved in $\beta$-lactamins resistance, the production of a $\beta$-lactamase, an enzyme hydrolyzing the $\beta$-lactam ring of the $\beta$-lactamins, is common. The emergence of ESBL and the widespread of this type of resistance is a major concern in animal and human health. Extended Spectrum $\beta$-lactamases are the enzymes having the ability to hydrolyze the $\beta$-lactam ring of broadspectrum $\beta$-lactams such as oxyimino-cephalosporins, including cefotaxime, ceftriaxone, and ceftazidime. These antibiotics are the so-called "third-generation cephalosporins". Because diverse types of ESBLs genes are usually plasmid-borne, and since the plasmids can be transferred among various species of Gram-negative bacteria, the genes for ESBLs can be acquired by this horizontal transfer mechanism (Kawamura et al., 2017).

In the present study, by using the double-disk synergy test, among 50 E. coli strains resistant to CTX, 39 (78\%) presented a classical synergy pattern of ESBL strains. Widespread resistance to newer generations of cephalosporins is attributed largely to the spread of CTX-M type Extended-spectrum $\beta$-lactamases (ESBLs) in Gram-negative bacteria, especially in Escherichia coli. As a result, the rapid global dissemination of the ESBL-producing E. coli is an emerging public-health concern (Pitout and Laupland, 2008).

In the current study, by using classical PCR (Tabar et al., 2016), the CTX-M gene has been identified in 27 (69.2\%) of the strains. Besides, CTX-M and ESBL can be TEM-derived or SHV-derived (Kawamura et al., 2017), so it is possible that the ESBL E. coli strains are of these types. Moreover, the used PCR amplified mainly the CTXM-2 family genes (Figure 7). However, CTX-M-type ESBLs have been roughly divided into four groups based on the sequence 
similarity in amino acid residues; CTX-M-1 group, CTX-M-2 group, CTX-M-9 group, and CTX-M-8/CTX-M-25 group (Naas et al., 2007; Kawamura et al., 2017). Therefore, it is also possible that the mentioned ESBL strains were from another CTX-M group. For example, CTX-M-15 which is common at this moment is a part of CTX-M-1 group and was the most isolated CTX-M gene in dairy cattle (Afema et al., 2018).

\begin{tabular}{|c|c|}
\hline СTX-M-1 & TCGGGAGGAAGACTGGGTGTGGCATTGATTAACACAGCAGATAATTCGCAAATACTTTAT \\
\hline CTX-M-9 & AGCGGAGGGCGGCTGGGCGTCGCGCTCATCGATACCGCAGATAATACGCAGGTGCTTTAT \\
\hline СТX-M-2 & TCGGGAGGTCGGCTTGGCGTTGCGCTGATTAACACCGCCGATAATTCGCAGATTCTCTAC \\
\hline CTX-M-25 & 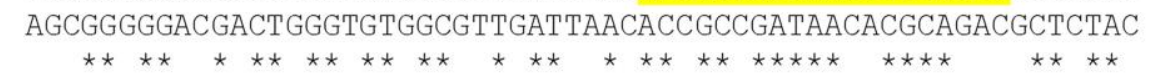 \\
\hline СТX-M-1 & CGTGCTGATGAGCGCTTTGCGATGTGCAGCACCAGTAAAGTGATGGCCGTGGCCGCGGTG \\
\hline СТX-M-9 & CGCGGTGATGAACGCTTTCCAATGTGCAGTACCAGTAAAGTTATGGCGGCCGCGGCGGTG \\
\hline СТX-M-2 & CGTGCCGATGAACGTTTTGCGATGTGCAGTACCAGTAAGGTGATGGCGGCCGCGGCGGTG \\
\hline CTX-M-25 & 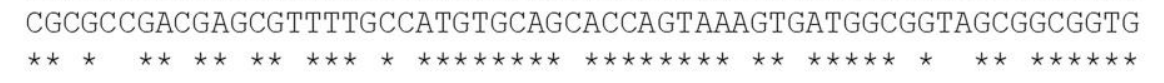 \\
\hline СТХ-M-1 & CTGAAGAAAAGTGAAAGCGAACCGAATCTGTTAAATCAGCGAGTTGAGATCAAAAAATCT \\
\hline СТХ-M-9 & CTTAAGCAGAGTGAAACGCAAAAGCAGCTGCTTAATCAGCCTGTCGAGATCAAGCCTGCC \\
\hline CTX-M-2 & CTTAAACAGAGCGAGAGCGATAAGCACCTGCTAAATCAGCGCGTTGAAATCAAGAAGAGC \\
\hline CTX-M-25 & 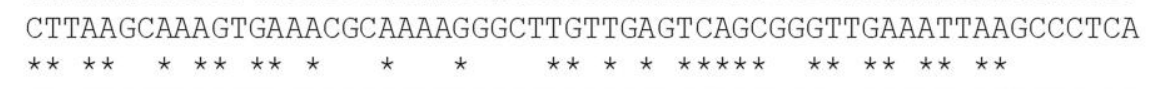 \\
\hline СтХ-M-1 & GACTTGGTTAACTATAATCCGATTGCGGAAAAGCACGTCGATGGGACGATGTCACTGGCT \\
\hline CTX-M-9 & GATCTGGTTAACTACAATCCGATTGCCGAAAAACACGTCAACGGCACAATGACGCTGGCA \\
\hline СTX-M-2 & GACCTGGTTAACTACAATCCCATTGCGGAGAAACACGTTAACGGCACGATGACGCTGGCT \\
\hline СTX-M-25 & 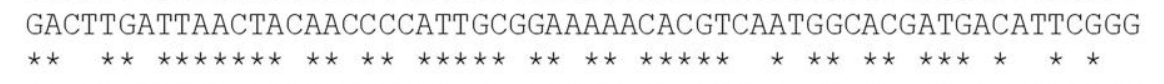 \\
\hline СТХ-M-1 & GAGCTTAGCGCGGCCGCGCTACAGTACAGCGATAACGTGGCGATGAATAAGCTGATTTCT \\
\hline СТX-M-9 & GAGCTGAGCGCGGCCGCGTTGCAGTACAGCGACAATACCGCCATGAACAAATTGATTGCC \\
\hline СТX-M-2 & GAGCTTGGCGCAGCGGCGCTGCAGTATAGCGACAATACTGCCATGAATAAGCTGATTGCC \\
\hline СTX-M-25 & 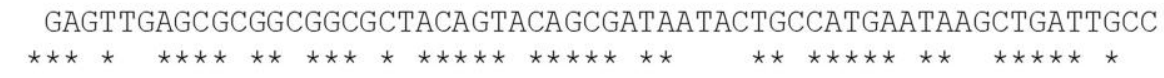 \\
\hline СТХ-M-1 & CACGTTGGCGGCCCGGCTAGCGTCACCGCGTTCGCCCGACAGCTGGGAGACGAAACGTTC \\
\hline СТХ-M-9 & CAGCTCGGTGGCCCGGGAGGCGTGACGGCTTTTGCCCGCGCGATCGGCGATGAGACGTTT \\
\hline СТХ-M-2 & CATCTGGGTGGTCCCGATAAAGTGACGGCGTTTGCTCGCTCGTTGGGTGATGAGACCTTC \\
\hline СTX-M-25 & 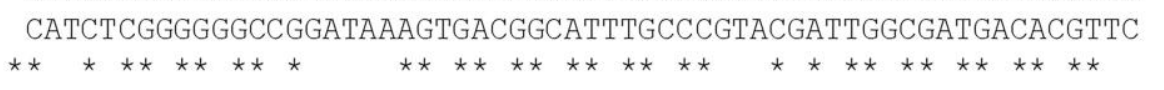 \\
\hline СТХ-M-1 & CGTCTCGACCGTACCGAGCCGACGTTAAACACCGCCATTCCGGGCGATCCGCGTGATACC \\
\hline СТХ-M-9 & CGTCTGGATCGCACTGAACCTACGCTGAATACCGCCATTCCCGGCGACCCGAGAGACACC \\
\hline СТX-M-2 & CGTCTGGACAGAACCGAGCCCACGCTCAATACCGCCATTCCAGGCGACCCGCGTGATACC \\
\hline СTX-M-25 & 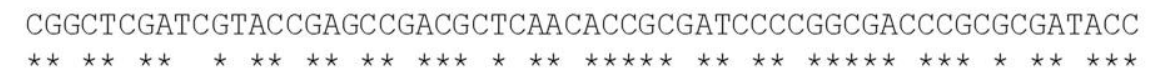 \\
\hline СТХ-M-1 & АCTTCACCTCGGGCAATGGCGCAAACTCTGCGTAATCTGACGCTGGGTAAAGCATTGGGT \\
\hline СТХ-M-9 & ACCACGCCGCGGGCGATGGCACAGACGTTGCGTCAGCTTACGCTGGGTCATGCGCTGGGC \\
\hline CTX-M-2 & ACCACGCCGCTCGCGATGGCGCAGACCCTGAAAAATCTGACGCTGGGTAAAGCGCTGGCG \\
\hline CTX-M-25 & 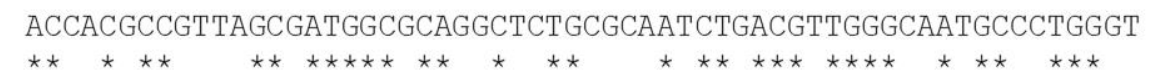 \\
\hline CTX-M-1 & GACAGCCAACGGGCGCAGCTGGTGACATGGATGAAAGGCAATACCACCGGTGCAGCGAGC \\
\hline СТХ-M-9 & GAAACCCAGCGGGCGCAGTTGGTGACGTGGCTCAAAGGCAATACGACCGGCGCAGCCAGC \\
\hline СтX-M-2 & GAAACTCAGCGGGCACAGTTGGTGACGTGGCTTAAGGGCAATACTACCGGTAGCGCGAGC \\
\hline СТX-M-25 & 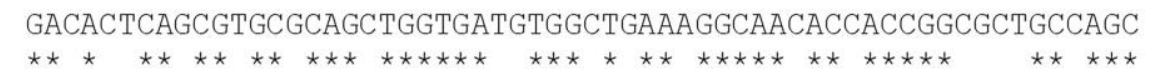 \\
\hline СТХ-M-1 & ATTCAGGCTGGACTGCCTGCTTCCTGGGTTGTGGGGGATAAAACCGGCAGCGGTGACTAT \\
\hline СТХ-M-9 & ATTCGGGCCGGCTTACCGACGTCGTGGACTGCAGGTGATAAGACCGGCAGCGGCGACTAC \\
\hline СТX-M-2 & ATTCGGGCGGGTCTGCCGAAATCATGGGTAGTGGGCGATAAAACCGGCAGCGGAGATTAT \\
\hline СTX-M-25 & $\begin{array}{l}\text { ATTCAGGCAGGGCTACCCACATCGTGGGTTGTCGGGGATAAAACCGGCAGCGGCGGTTAT } \\
* * * * * * * * * * * \quad * * * * * \quad * * * * * * * * * * * * * * * * * * * * *\end{array}$ \\
\hline СTX-M-1 & GGCACCACCAACGATATCGCGGTGATCTGGCCAAAAGATCGTGCGCCGCTGATTCTGGTC \\
\hline СтХ-М-9 & GGCACCACCAATGATATTGCGGTGATCTGGCCGCAGGGTCGTGCGCCGCTGGTTCTGGTG \\
\hline СТX-M-2 & GGCACCACCAACGATATCGCGGTTATCTGGCCGGAAAACCACGCACCGCTGGTTCTGGTG \\
\hline CTX-M-25 & GGTACGACGAATGATATCGCGGTTATTTGGCCGGAAGGTCGCGCGCCGCTCGTTCTGGTG \\
\hline
\end{tabular}

Figure 7. Alignment of the main CT-X-M sequences using ClustalOmega software. CT-X-M-1 (genbank NG_048897.1), CTX-M-2 (genbank NG_048968.1), CTX-M-9 (genbank NG_049043.1), and CTX-M-25 (genbank NG_048974.1). The sequences of the used primers were highlighted. The identities were indicated by a star. The numbers corresponded to the number of the genbank sequences. 
In conclusion, the finidngs of the current study have indicated that cows producing milk are commonly positive to CMT test, and subclinical mastitis is an underestimated problem in Algeria. Escherichia coli is frequently isolated in cow milk indicating an improper hygiene level in the farms and an inappropriate disinfection procedure at the milking.

Antibiotic resistance is a major concern in animal and human medicine. The increase of MDR strains in animals and humans leads more and more to therapeutic dead ends. Most of the E. coli isolates were found as MDR, and a particular focus was put on ESBL. Of the studied E. coli, $40 \%$ were ESBL-carriers. Although animals should be cared for, the sparing use of antibiotics is recommended. In any case, the use of antibiotics as a growth promoter should be prohibited.

\section{DECLARATIONS}

\section{Author's contributions}

Ghallache Loubna and Mohamed-Cherif Abdellah conceived the study design, carried out laboratory work, participated in data analysis and interpretation, drafted the manuscript. Ghallache Loubna and Mohamed-Cherif Abdellah contributed equally to this work. China Bernard conceived the study design, participated in data analysis and interpretation, revised the manuscript. Benfodil Karima conceived the study design, drafted and revised the manuscript. Miroud Kamel revised the manuscript. Ait-Oudhia Khatima conceived the study design, took part in the coordination and management as well as field studies, participated in data analysis and interpretation, and revised the manuscript.

\section{Competing interests}

The authors declare that they have no conflict of interest.

\section{Acknowledgments}

The authors wish to thank the Algerian Ministry of Higher Education and Scientific Research for their contribution to my Ph.D. training and Dr. Benbouras Mohamed Amin of the high national polytechnic School of Algiers for making up the geographical maps.

\section{Ethical considerations}

Ethical issues (including plagiarism, consent to publish, misconduct, data fabrication and/or falsification, double publication and/or submission, and redundancy) have been checked by the authors.

\section{REFERENCES}

Afema JA, Ahmed S, Besser TE, Jones LP, Sischo WM , Davis MA (2018). Molecular Epidemiology of Dairy Cattle-Associated Escherichia coli

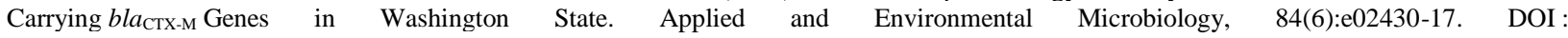
https://www.doi.org/10.1128/AEM.02430-17

Aggad H, Mahouz F, Ahmed Ammar Y,and Kihal M (2009).Evaluation de la qualité hygiénique du lait dans l'ouest algérien. Revue de Médecine Véterinaire, 160:590-595. Available at : https://www.revmedvet.com/artdes-fr.php?id=1769

Ameen F, Reda SA, El-Shatoury SA, Riad EM, Enany ME, Alarfaj AA(2019). Prevalence of antibiotic-resistant mastitis pathogens in dairy cows in Egypt and potential biological control agents produced from plant endophyticactinobacteria Saudi Journal of Biological Sciences, 26:1492-1498. DOI: https://www.doi.org/10.1016/j.sjbs.2019.09.008

Asnoune ZB, Butel MJ, and Ouzrout R (2012).Prévalence des principales bactéries responsables de mammites subcliniques des vaches laitières au nord-est de l'Algérie. Review of breeding and veterinary medicine of tropical countries,65:5-9. DOI: https://www.doi.org/10.19182/remvt.10132

Avrain L, Humbert F, L'Hopsitalier R, Sanders P, Vernozy- Rozand C,Kempf I (2003).Antimicrobial resistance in Campylobacter from broilers: Association with production type and antimicrobial use. Veterinary Microbiology, 96:267-276. DOI: https://www.doi.org/10.1016/j.vetmic.2003.07.001

Baazise D (2006). Evaluation de la qualité microbiologique du lait cru de vache dans la région de la Mitidja. Mémoire de magister, Département des sciences vétérinaires, Université de Blida: 198p. Available at : http://di.univ-blida.dz:8080/jspui/bitstream/123456789/475/1/06\%20M.MTA.pdf

Barbour EK , Kassabian TJ, Shaib H, Kassaify Z, Iyer A, Azhar E, Harakeh S ,Kumosani T (2015). The significance of Escherichia coli-induced mastitis in cows associated with the presence of virulence genes and wide range-resistance to twenty antimicrobials. International Journal of Applied Research in Veterinary Medicine, 13: 51-63. Available at: https://www.cabdirect.org/cabdirect/abstract/20153215249

Boonyasiri A, Tangkoskul T, Seenama C, Saiyarin J, Tiengrim S, Thamlikitkul V(2014). Prevalence of antibiotic resistant bacteria in healthy adults, foods, food animals, and the environment in selected areas in Thailand. Pathogens and Global Health, 108:235-245. DOI: https://www.doi.org/10.1179/2047773214Y.0000000148

Botrel, MA, Haenni M, Morignat E, Sulpice P, Madec JY, Calavas D (2010). Distribution and antimicrobial resistance of clinical and subclinical mastitis pathogens in dairy cows in Rhone- Alpes, France. Foodborne Pathogens and Disease, 7:479-487. DOI: https://www.doi.org/10.1089/fpd.2009.0425

Brown DF, and Kothari D (1975). Comparison of antibiotic discs from different sources. Journal of Clinical Pathology, 28:779-783. DOI: https://www.doi.org/10.1136/jcp.28.10.779

Burvenich C, Merris VV, Mehrzad J, Diez-Fraile A, Duchateau L(2003).Severity of E. coli mastitis is mainly determined by cow factors. Veterinary Research, 34:521-564. DOI: https://www.doi.org/10.1051/vetres:2003023

Cepas V, and Soto SM (2020). Relationship between Virulence and Resistance among Gram-Negative Bacteria. Antibiotics (Basel, Switzerland), 9(10): 1-11. DOI: https://www.doi.org/10.3390/antibiotics9100719 
Chang HH, Cohen T, Grad YH, Hanage WP, O'Brien TF, Lipsitch M (2015). Origin and proliferation of multiple-drug resistance in bacterial pathogens. Microbiol Mol Biol Reviews, 79(1):101-116. DOI: https://www.doi.org/10.1128/MMBR/00039-14

Collignon P, Powers JH, Chiller TM, Aidara-Kane A, Aarestrup FM (2009).World Health Organization ranking of antimicrobials according to their importance in human medicine: A critical step for developing risk management strategies for the use of antimicrobials in food production animals. Clinical Infectious Diseases: An Official Publication of the Infectious Diseases Society of America, 49:132-141. DOI: https://www.doi.org/10.1086/599374

Defays D (1977). An efficient algorithm for a complete link method, The Computer Journal, 20: 364-366. DOI https://doi.org/10.1093/comjnl/20.4.364

Djahnit N, Chernai S, Catania V, Hamdi B, China B, Cappello S, Quatrini P (2018). Isolation, characterization and determination of biotechnological potential of oil-degrading bacteria from Algerian centre coast. J Appl Microbiol,126(3):780-795. DOI : https://doi.org/10.1111/jam.14185

Société Française de Microbiologie (SFM) Comité de l'antibiogramme (2019). European Committee on Antimicrobial Suscpetibility Testing, recommandations 2019, Paris, 2019. Available at: CASFM2019 V1.0.pdf (sfm-microbiologie.org)

Drieux L, Brossier F, Sougakoff W, and Jarlier V (2008).Phenotypic detection of extended-spectrum beta-lactamase production in Enterobacteriaceae: Review and bench guide. Clinical Microbiology and Infection: The Official Publication of the European Society of Clinical Microbiology and Infectious Diseases, 1:90-103. DOI: https://www.doi.org/10.1111/j.1469-0691.2007.01846.x

Fazel F, Jamshidi A, and Khoramian B (2019). Phenotypic and genotypic study on antimicrobial resistance patterns of E. coli isolates from bovine mastitis. Microbial Pathogenesis, 132:355-361. DOI : https://www.doi.org/10.1016/j.micpath.2019.05.018

Gouvêa R, Dos Santos FF, and De Aquino MHC (2015). Fluoroquinolones in industrial poultry production, bacterial resistance and food residues: A review. Brazilian Journal of Poultry Science, 17:1-10. DOI: https://www.doi.org/10.1590/1516-635x17011-10

Green MR and Sambrook J (2019). Agarose Gel Electrophoresis. Cold Spring Harb Protoc, (1). DOI: https://www.doi.org/10.1101/pdb.prot100404

Guess MJ, Wilson SB(2002). Introduction to hierarchical clustering. J Clin Neurophysiol, (2):144-51. DOI: https://www.doi.org/10.1097/00004691200203000-00005

Haftu R, Taddele H, Gugsa G, and Kalayou S (2012). Prevalence, bacterial causes, and antimicrobial susceptibility profile of mastitis isolates from cows in large-scale dairy farms of Northern Ethiopia. Tropical Animal Health and Production, 44:1765-1771. DOI: https://www.doi.org/10.1007/s11250-012-0135-Z

Halasa T, Nielen M, De Roos AP, Van Hoorne R, de Jong G, Lam TJ, van Werven T, Hogeveen H(2009). Production loss due to new subclinical mastitis in Dutch dairy cows estimated with a test-day model. J Dairy Sci, 92(2):599-606. DOI: https://www.doi.org/10.3168/jds.2008-1564

Ismail ZB, and Abutarbush SM (2020). Molecular characterization of antimicrobial resistance and virulence genes of Escherichia coli isolates from bovine mastitis. Veterinary World, 13:1588-1593. DOI: https://www.doi.org/10.14202/vetworld.2020.1588-1593

Huet, T., Turbelin, C., Esquevin, S., Grisoni, M. L. (2021). BiostaTGV software. Available at: https://biostatgv.sentiweb.fr/\#main\%20view\%20online\%2027/06/2021

Kawamura K, Nagano N, Suzuki M, Wachino J, Kimura K, Arakawa Y(2017). ESBL-producing Escherichia coli and Its Rapid Rise among Healthy People. Food Safety (Tokyo, Japan), 5:122-150. DOI: https://www.doi.org/10.14252/foodsafetyfscj.2017011

Krumperman PH (1983). Multiple antibiotic resistance indexing of Escherichia coli to identify high-risk sources of fecal contamination of foods. Applied and Environmental Microbiology, 46:165-170. DOI: https://www.doi.org/10.1128/AEM.46.1.165-170.1983

Kohn MA, Senyak J. Sample Size Calculators [website]. UCSF CTSI. 29 April 2021. Available at https://www.sample-size.net/

Leach KA, Green MJ, Breen JE, Huxley JN, Macaulay R, Newton HT, Bradley AJ (2008). Use of domestic detergents in the California mastitis test for high somatic cell counts in milk. The Veterinary Record, 163:566-570. DOI: https://www.doi.org/10.1136/vr.163.19.566

Liu G, Ali T, Gao J, Ur Rahman S, Yu D, Barkema HW, Huo W, Xu S, Shi Y, Kastelic JP, Han B(2020). Co-occurrence of plasmid-mediated colistin resistance (mcr-1) and extended-spectrum $\beta$-lactamase encoding genes in Escherichia coli from bovine mastitic milk in China. Microbial Drug Resistance, 26:685-696. DOI : https://www.doi.org/10.1089/mdr.2019.0333

Ministère de l'agriculture et du développement rural (MADR) (2003).Rapport National sur les Ressources Génétiques Animale : Algérie. Commission nationale AnGR, 45 pages. Available at: http://www.fao.org/3/a1250e/annexes/CountryReports/Algeria.pdf

Magnusson M, Christiansson A, and Svensson B (2007).Bacillus cereus spores during housing of dairy cows: Factors affecting contamination of raw milk. Journal Of Dairy Science, 90:2745-2754. DOI: https://www.doi.org/10.3168/jds.2006-754

Manyi-Loh C, Mamphweli S, Meyer E, and Okoh A (2018). Antibiotic use in agriculture and Its consequential Resistance in environmental sources: potential public health implications. Microbial Drug Resistance (Larchmont, N.Y.), 23:1-48. DOI : https://www.doi.org/10.3390/molecules230407951

Ministère de la santé, de la population et de la réforme hospitalièr (MSPRH) (2014). Algerian network for monitoring bacterial resistance to antibiotics, standardization of antibiotic sensitivity tests at the national level (human and veterinary medicine) 178 pages. Available at: www.sante.gov.dz/aarn/index

Naas T, Oxacelay C, and Nordmann P (2007). Identification of CTX-M-type extended-spectrum-beta-lactamase genes using real-time PCR and pyrosequencing. Antimicrobial Agents and Chemotherapy, 51:223-230. DOI: https://www.doi.org/10.1128/AAC.00611-06

Nüesch-Inderbinen M, Käppeli N, Morach M, et al (2019).Molecular types, virulence profiles and antimicrobial resistance of Escherichia coli causing bovine mastitis. Veterinary Record Open, 6:000369. DOI: https://www.doi.org/10.1136/vetreco-2019-000369

Official Journal of the European Union (OJEU) (2003). European Union. Regulation (EC) No 1831/2003 of the European Parliament and of the Council of 22 September 2003 on additives for use in animal nutrition. Offical Journal of the European Union, 268, 29-43. Available at: https://eur-lex.europa.eu/eli/reg/2003/1831/oj

Okoko IM, Maina N, Kiboi D, and Kagira J (2020). $\beta$-lactam resistance in bacteria associated with subclinical mastitis in goats in Thika Subcounty, Kenya. Veterinary World, 13:1448-1456. DOI: https://www.doi.org/10.14202/vetworld.2020.1448-1456

Olivares-Pérez J, Kholif AE, Rojas-Hernández S, et al (2015). Prevalence of bovine subclinical mastitis, its etiology and diagnosis of antibiotic resistance of dairy farms in four municipalities of a tropical region of Mexico. Tropical Animal Health and Production, 47:1497-1504. DOI: https://www.doi.org/10.1007/s11250-015-0890-8

Ombarak RA, Hinenoya A, Elbagory ARM, and Yamasaki S (2018). Prevalence and molecular characterization of antimicrobial resistance in Escherichia coliisolated from raw milk and raw milk cheese in Egypt. Journal of Food Protection, 81:226-232. DOI https://www.doi.org/10.4315/0362-028X.JFP-17-277

Österberg J, Wingstrand A, Nygaard Jensen A, Kerouanton A, Cibin V, Barco L, Denis M, Aabo S, Bengtsson B (2016).Antibiotic Resistance in Escherichia coli from Pigs in Organic and Conventional Farming in Four European Countries. PLoS One, 11:0157049. DOI: https://www.doi.org/10.1371/journal.pone.0157049. 
Peton V, and Le Loir Y (2014). Staphylococcus aureus in veterinary medicine. Infection, Genetics and Evolution: Journal of Molecular Epidemiology and Evolutionary Genetics in Infectious Diseases, 21:602-615. DOI : https://www.doi.org/10.1016/j.meegid.201

Pilet C, Bourdon JI (1979). Bactériologie médicale et vétérinaire, systématique bactérienne. 2éme édition. Doin .paris. ISBN: 2-7040-0362-9.

Pitout JDD, and Laupland KB (2008). Extended-spectrum beta-lactamase-producing Enterobacteriaceae: an emerging public-health concern. Lancet Infectious Disease, 8:159-166. DOI: https://www.doi.org/10.1016/S1473-3099(08)70041-0.

Rangel P, and Marin JM (2009). Analysis of Escherichia coli isolated from bovine mastitic milk. Pesquisa Veterinária Brasileira, 29:363-368. DOI : http://www.dx.doi.org/10.1590/S0100-736X2009000500001

Saberfar E, Pourakbari B, Chabokdavan K, and Dolatshahi FT (2008).Antimicrobial susceptibility of Escherichia coli isolated from Iranian broiler chicken flocks, 2005-2006. Journal of Applied Poultry Research, 17:302-304. DOI: https://www.doi.org/10.3382/japr.2007-00102

Saidani M, Messadi L, Soudani A, et al (2018).Epidemiology, Antimicrobial Resistance, and Extended-Spectrum Beta-Lactamase-Producing Enterobacteriaceae in Clinical Bovine Mastitis in Tunisia. Microbial Drug Resistance (Larchmont, N.Y.), 24:1242-1248. DOI: https://www.doi.org/10.1089/mdr.2018.0049

Saini,V., McClure,J.T, Le'gerD., Keefe, G.P, Scholl, D.T, Morck,D.W, Barkema,H.W (2012). Antimicrobial resistance profiles of common mastitis pathogens on Canadian dairy farms. Journal Of Dairy Science, 95:4319-4332. DOI: https://www.doi.org/10.3168/jds.2012-5373

Sharif A, and Muhammad G (2009). Mastitis control in dairy animals. Pakistan Veterinary Journal, 29:145-148. Available at: https://citeseerx.ist.psu.edu/viewdoc/download?doi=10.1.1.602.1277\&rep=rep1\&type=pdf

Schoonjans, F. (2017). Madcalc manual, Easy-to-use statistical software. $17^{\text {th }}$ edition. Medcalc software, Ostend, Belgium. ASIN: B01MZ75LX4. Available at: www.medcalc.org

Tabar MM, Mirkalantari S, and Amoli RI (2016). Detection of ctx-M gene in ESBL-producing $E$. coli strains isolated from urinary tract infection in Semnan, Iran. Electron Physician, 8:2686-2690. DOI: https://www.doi.org/10.19082/2686

Tahar S, Nabil MM, Safia T, Ngaiganam EP, Omar A, Hafidha C, Hanane Z, Rolain JM, Diene SM (2020). Molecular Characterization of MultidrugResistant Escherichia coli Isolated from Milk of Dairy Cows with Clinical Mastitis in Algeria. Journal of Food Protection, 83:2173-2178. DOI: https://www.doi.org/10.4315/JFP-20-198

ThrusfieldM, and Christley R (2018). Veterinary epidemiology, 4th Edition, Wiley-blackwell editions. Hoboken, NJ, USA, pp. 888. Available at: https://www.wiley.com/en-us/Veterinary+Epidemiology\%2C+4th+Edition-p-9781118280287

Verbeke J, Piepers S, Supré K, and De Vliegher S (2014). Pathogen-specific incidence rate of clinical mastitis in Flemish dairy herds, severity, and association with herd hygiene. Journal Of Dairy Science 97:6926-6934. DOI: https://www.doi.org/10.3168/jds.2014-8173

Wessa P (2021). Free Statistics Software, Office for Research Development and Education, version 1.2.1. Available at: https://www.wessa.net/

Yu ZN, Wang J, Ho H, Wang YT, Huang SN, Han RW (2020). Prevalence and antimicrobial-resistance phenotypes and genotypes of Escherichia coli isolated from raw milk samples from mastitis cases in four regions of China. Journal of Global Antimicrobial Resistance, 22:94-101. DOI: https://www.doi.org/10.1016/j.jgar.2019.12.016 